Geologica Macedonica, Vol. 34, No. 2, pp. 137-148 (2020)

In print ISSN $0352-1206$

On line ISSN $1857-8586$

UDC: 551.311:[528.88:004.6(497.75)

\title{
PREPARATION OF GIS LANDSLIDE INVENTORY FOR THE POLOG REGION
}

\author{
Nataša Nedelkovska ${ }^{1}$, Igor Peševski ${ }^{2}$, Milorad Jovanovski ${ }^{2}$, \\ Jovan Papić́ ${ }^{2}$, Svemir Gorin ${ }^{3}$, Ivan Radevski ${ }^{3}$ \\ ${ }^{I}$ Geohydroconsulting Ltd., Skopje, \\ Manapo Str. No.7-2/5, MK-1000, Skopje, Republic of North Macedonia \\ ${ }^{2}$ Faculty of Civil Engineering, "Ss. Cyril and Methodius" University in Skopje, \\ Blvd. Partizanski odredi 24, MK-1000, Skopje, Republic of North Macedonia \\ ${ }^{3}$ Faculty of Natural Sciences and Mathematics, "Ss. Cyril and Methodius" University in Skopje, \\ Arhimedova Str. 3, MK-1000, Skopje, Republic of North Macedonia \\ n_nedelkovska@hotmail.com
}

\begin{abstract}
A b s t r a c t: This paper deals with preparation of Geographic Information Systems (GIS) landslide inventory for the Polog region. A number of activities were undertaken for this purpose, such as: analysis of own data on landslides, visits of the sites noted in the surveys filled by municipalities, digitizing of landslides from old geological maps in scale 1:25000, analysis and digitizing of landslides from the archive of the Geological Survey of Macedonia, interviews with employees and retired colleagues from geotechnical companies, analysis of landslides along the channels of the "Mavrovo" system, visit to the National University in Tetovo and joint site visit, and visits to several geotechnical companies in Macedonia. Since this is the first attempt to create a regional landslide inventory in N. Macedonia, the adopted structure of the inventory is presented in the paper. Moreover, to see what benefits can be gained from the availability of such inventory some of the most important findings regarding the landslides are presented further. Currently the inventory consists of 136 occurrences, and in time it should be appropriately updated. The main findings related to the distribution and characteristics of the landslides show that future analyses should include preparation of landslide susceptibility/hazard models both for shallow and deep landslides, as well as for flow-like type of slides. In the following stages of investigation, it is planned to analyze a LIDAR (LIght Detection and Ranging) survey that is being prepared for the region and incorporate more landslides in the inventory. Also, findings of the InSAR (Interferometric Synthetic Aperture Radar) analysis will be combined with the inventory, which will lead to conclusions on the movement rates of detected sites. The latter two approaches will be presented in future papers.
\end{abstract}

Key words: landslide; GIS; inventory; Polog region

\section{INTRODUCTION}

Landslides present a significant natural hazard, especially in mountainous and hilly regions. Hence, landslide susceptibility, hazard and risk assessments are required in order to perform appropriate risk management.

Landslide inventories are the basis for landslide susceptibility, hazard and risk assessment (Van Westen et al., 2008; Hervás \& Bobrowsky, 2009; Blahut et al., 2010; Calvello and Pecoraro, 2018). A complete definition of landslide inventories and their content can be found in Hervás, 2013: “A landslide inventory is a detailed register of the distribution and characteristics of past landslides. For each landslide recorded in an inventory, core information usually includes a unique identification code (ID number), landslide site name (for major landslides), location (geographical coordinates, municipality, province or county, region or state), type of landslide, date of occurrence if known or last reactivation, state of activity, and volume (or surface extent). Additional information may include landslide geometry (surface dimensions, depth of failure surface), geology (lithology, structure, material properties), hydrogeology, land cover or use, slope geometry, triggering cause, impact (e.g., casualties, damage expressed in economic value or in descriptive terms), remedial measures, surveying methods and date, and surveyor's name and bibliographical references. Complementary data such as illustrations (ground or aerial photographs, drawings) and mo- 
nitoring data (type of instrumentation, rate of movement) can sometimes be found in an inventory."

Reviewing the literature, it was noticed that the inventories are characterizing with heterogeneous completeness and accuracy. Landslide inventories developed at global, continental and national scales, differently from the once produced over smaller areas, often lack details of the inventoried phenomena, such as their areal distribution or insights into their type, size, activity and causal factors (Calvello and Pecoraro, 2018).

At global scale, Kirschbaum et al. (2010) compiled a landslide catalog for 3 years for rainfalltriggered events. Petley (2012) prepared a global data set of 2620 nonseismically triggered landslides for the period between 2004 and 2010.

Sepulveda and Petley (2015) presented a continental database of 611 landslides that caused loss of life in Latin America and the Caribbean from 2004 to 2013.

National landslide inventories exist in many countries. Mirus et al. (2020) prepared a comprehensive map of landslide occurrences across the United States (USA), through a national scale compilation of existing, publicly available landslide inventories. The geodatabase has total of 310392 landslides and can be viewed through http://www. usgs.gov/maps/national-landslides-map-and-data, searchable map, with parsimonious attributes and direct links to the contributing sources with additional details.

Li et al. (2016) describe the development, visualization and analysis of a China's Landslide Inventory Database (CsLID) by utilizing Google's public cloud computing platform. The CsLID compiles a total of 1221 historical landslide events spanning the years 1949-2011 from relevant data sources.

The British Geological Survey (BGS) has developed the National Landslide Database of Great Britain, with over 17000 records of landslide events, each documented as fully as possible (Pennington et al., 2015). Data are gathered through a range of procedures, including: incorporation of other databases; automated trawling of current and historical scientific literature and media reports; new field- and desk-based mapping technologies with digital data capture, and using citizen science through social media and other online resources.

Damm and Klose (2015) present a national archive landslide database for the Federal Republic of Germany. The database offers due to systematic and continuous regional data compilation of a differentiated data pool of more than 5000 data sets and over 13000 single data files. It dates back to 1137 $\mathrm{AD}$ and covers landslide sites throughout Germany. Beside information on landslide attributes, the database includes data on landslide impact sand hazard mitigation.

The IFFI project (Italian Landslide Inventory), carried out by ISPRA and the Regions and Autonomous Provinces, and supplies a detailed picture of the distribution of landslide phenomena within Italy. The inventory has recorded to date 620808 landslides affecting an area of about $23700 \mathrm{~km}^{2}$, or $7.9 \%$ of the national territory (ISPRA, 2018).

The Polish national landslide inventory has been developing from 2008, managed by the Polish Geological Institute. The database includes records of about 34039 landslides with a mapped area of $10903 \mathrm{~km}^{2}$ in the Polish Carpathians (http://geopor tal.pgi.gov.pl/portal/page/portal/SOPO/Wyszukaj3. Inventory map in scale 1:10000 has been prepared, mostly by geomorphological field mapping and partially using historical documents and visual analysis of SAR and LIDAR data (Mrozek et al., 2014).

Reviewing the Balkan countries, it was found that Slovenia has a modern national landslide database, with total number of 6234 landslide records (Komac and Hribernik, 2015). Albanian Geological Survey has developed the National Landslide Database between 2011 and 2015 and a total of 3050 landslides were documented using a combination of historical documents and archive data, aerial photo and Google earth interpretation with field verification (Jaupaj et al., 2017). Bosnia and Herzegovina has national landslide database with 1500 landslides, Bulgaria with 1107 landslides and Greece with 2200 landslides, while for Croatia, Romania and Serbia only information on regional landslide databases was available (Van den Eeckhaut and Hervás, 2012). In the same paper, also the national database of Macedonia (called Landslide Cadastre) is included, which contains a total of 150 landslides, with assessed completeness of $50-75 \%$, and available inventory map in scale 1:100000, which is not in a digital form. These landslides were mapped during preparation of the Basic Geological Map in 1970.

In the period between 2011 and 2014 Peshevski et. al. (2014) prepared GIS (Geographic Information System) Inventory Map of the country, consisting of 250 occurrences.

Peshevski et. al. (2015), did an attempt to prepare regional landslide inventory for the PologReka region, using available geological maps 
(1:25000 to 1:100000), Google Earth, a Digital Elevation Model with resolution of $5 \mathrm{~m}$, GIS-portal of the National Agency for Real Estate, ortho-photo images at a scale of 1:5.000, topographic (1:25000) and geological maps (1:1000 - 1:5000) of past landslides. In this way, many slope instabilities were identified, but the accuracy of this inventory was considered rather low, since for most of the landslides their main attributes were unknown.

In further studies dealing with landslide susceptibility and hazard assessment in Polog region
(Peshevski et. al., 2019), it was concluded that improvement of the quality of the landslide inventory for the region is necessary, because the appropriate selection and validation of the susceptibility (or hazard) models depends on the accuracy and completeness of the inventory.

In this paper preparation of landslide inventory for Polog region is presented. This is the first attempt for establishment of regional landslide inventory in Macedonia through systematic collection of data supported by field checks.

\section{LANDSLIDE DATA COLLECTION}

The Polog region is located in the northwest part of the Republic of North Macedonia (Figure 1). It is characterized by mountainous topography and dense hydrographic network comprising torrential streams and rivers, as well as by high population density along the Shara Mountain range and along the Vardar river. Historically, this region has been exposed to extreme weather conditions and frequent flooding. A number of devastating flash floods happened in 2015 and 2016 when human and economic losses were huge (Peshevski et al., 2017). The losses were caused by violent streams but also by inappropriate land-use, such as construction in flood plains, rapid illegal urbanization in hazard zones and constricted river courses, and increased erosion due to logging in forests. All these changes are altering the hydrological processes and regimes, increasing the risk of floods and associated effects, such as landslides, rockfalls, mudflows, and promotion of other unfavorable geological processes. The disaster of such events is influenced also by climate change and increase in the frequency of hydrological extremes as well as from other causes such as incomplete and poorly maintained riverbeds and infrastructure.

In the Polog region geological formations can be found from almost all geological periods, from the Cambrian to the Quaternary period, with different types of igneous, sedimentary and metamorphic rocks present in the region. The geomorphological settings which are dependent mostly on the complex geology, and the specific hydrometeorological conditions, are the main preconditioning factors for this region to be classified as "landslide prone". The Polog region belongs to seismic zones where the maximum expected seismic intensities of 7, 8 and 9 are likely (according to the MSK scale) for return periods of 100 and 500 years.

The activities for preparation of the Polog region landslide inventory were performed during a period of 4 months, between November 2019 and June 2020. The activities consisted of:

- Analysis of own data on landslides.

- Visits of the sites noted in surveys filled by municipalities representatives.

- Digitizing of landslides from old geological maps in scale 1:25000.

- Analysis and digitizing of landslides from the archive of the Geological Survey of Macedonia.

- Interviews with employees and retired colleagues from geotechnical companies.

- Analysis of landslides along the channels of the "Mavrovo" system for hydroenergy production.

- Visit to the National University in Tetovo and joint site visit.

- Visits to several geotechnical companies in Macedonia.

Analysis of own data comprised searching the archive of the Faculty of Civil Engineering and digitizing of landslides in GIS environment. Since some of the documentation is incomplete or without maps, it was not possible to define the exact landslide polygons. This restriction refers also to some landslides from other data sources. For several landslides, the polygons were defined with the help of older retired colleagues.

All municipalities that answered a previously prepared survey were visited; landslides were located and then mapped. During the process, it was found that landslide data collection and archiving is one of the main issues in the municipalities. There are no official or unofficial databases in the municipalities. Due to the new administrative organization of the country as of 2004, several new municipalities were established, so it is very possible that some information which was previously available has been lost. The municipalities record only some provisional data of recent events, although even this data is scarce and incomplete. 
Landslides from the geological maps of 1:25000 and those from the archive of the Geolo- gical Survey of Macedonia were digitized in GIS and basic parameters of landslide were extracted.
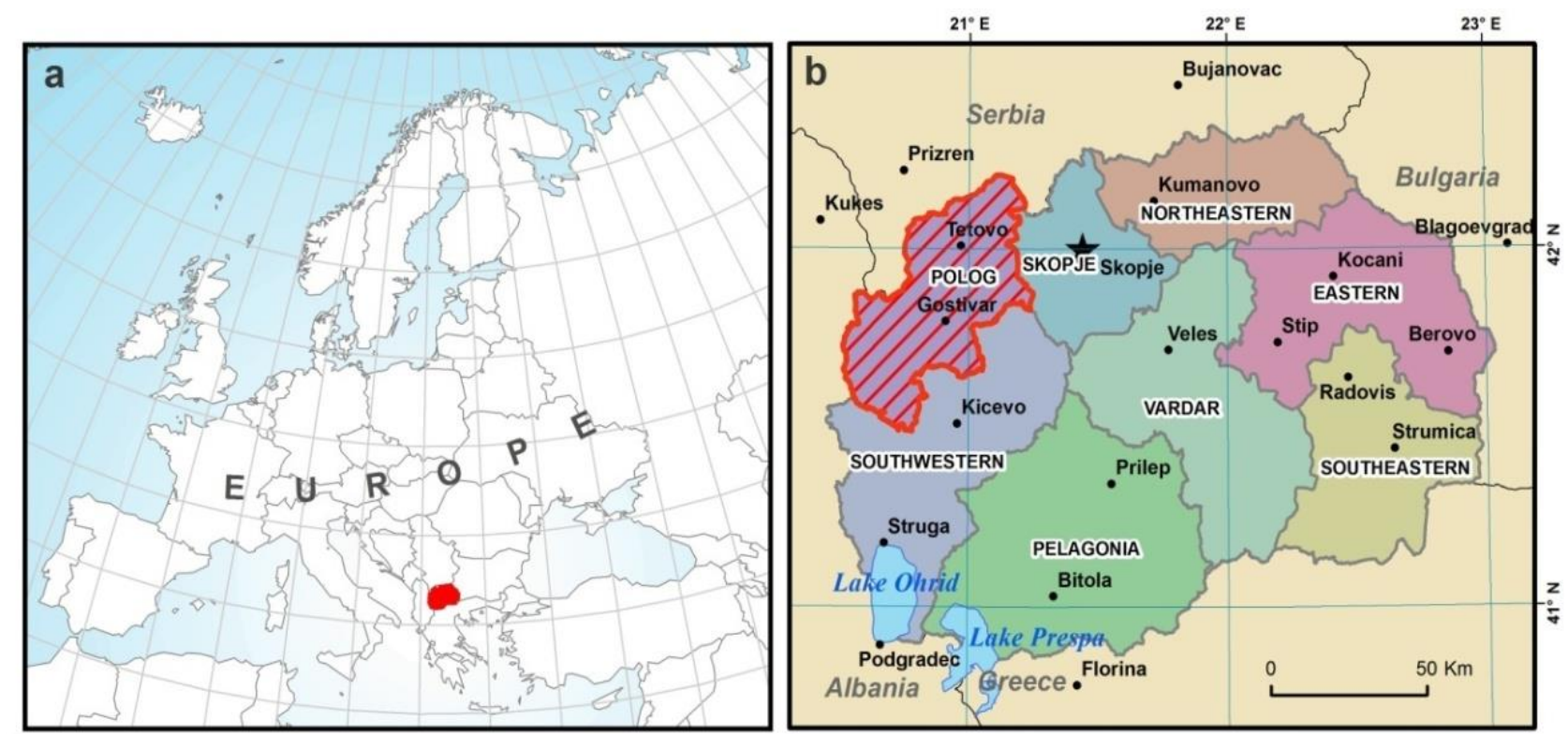

Fig. 1. a) Location of the Republic of North Macedonia in Europe b) Location of the case study region of Polog

Landslides along the channels of the "Mavrovo" system for hydroenergy production were digitized with colleagues from the company. It is noticed that in comparison with the municipalities, the "Mavrovo" personnel holds organized data for landslide occurrences (even though on very basic level). Landslides from this data source are very important since they occur at higher altitudes above the settled places in Polog and pose a threat to the population and the property below.

Some landslides that we had only narrative reports thereof were mapped with the help of colleagues from the National University in Tetovo. The same process was conducted for several other landslides with the help of colleagues working in geotechnical companies.

\section{STRUCTURE OF THE LANDSLIDE INVENTORY}

As mentioned earlier, the landslide inventory is compiled from different data sources, each with different quality and precision of data. For example, landslides from the geological maps 1:25000 were mapped in the period 1960-1970, but their exact time of occurrence is probably much earlier. For some landslides their borders were defined according to the memory of engineers who worked in the field in the past. For some of the most recent landslides there is even no data about damages, etc. Due to these restrictions, we were unable to prepare a more advanced inventory so we had to adopt only the following fields (Table 1 and Figure 2). If we compare with the definition of Hervás (2013), however we can conclude that the most important elements are considered. This is in line with the world literature, which suggests that, in order to create a base for high quality hazard models of regions, only the reliable data should be entered in the databases. For several occurrences from the inventory we were unable to fill some of the fields presented in Table 1.

For each of the visited sites, a photo album was created, while positioning was done by a GPS device. Notes were taken in a field diary with sketches of the landslides. Outlines of the landslides were later drawn in office in a GIS and all the data was entered in appropriate EXCEL and GIS attribute table (the database). All information can be transferred in KMZ file format that enables upload in "Google Earth Application" for clear visual presentation for laymen and not only experts. Currently the landslide inventory consists of 136 occurrences. Cartographic presentation of the landslide inventory is presented on the map in Figure 3. 
Table 1

\section{Structure of the Polog landslide inventory}

\begin{tabular}{|c|c|}
\hline ID Number & \\
\hline \multirow{4}{*}{ Location } & Geographic position (x)_Latitude (WGS84 $\left.{ }^{1}\right)$ \\
\hline & Geographic position (y)_L Longitude (WGS84 ${ }^{1}$ ) \\
\hline & Elevation $(\mathrm{m})$ \\
\hline & Name of locality \\
\hline Geology & Basic geology settings of terrain \\
\hline \multirow{3}{*}{ Activity state } & Date of occurrence \\
\hline & Last change in activity \\
\hline & General state of activity \\
\hline \multirow{5}{*}{ Landslide properties } & Type of movement \\
\hline & Area $\left(\mathrm{m}^{2}\right)$ \\
\hline & Direction of movement \\
\hline & Landslide trigger/precondition \\
\hline & Depth of landslides ( $<2 \mathrm{~m}$ shallow and $>2 \mathrm{~m}$ deep) \\
\hline \multirow{3}{*}{ Costs } & Damages (only provisional data) \\
\hline & Sanation measures \\
\hline & Monitoring \\
\hline Source of data & $\begin{array}{l}\text { Institution holding documentation } \\
\text { Other important remarks for the occurrence }\end{array}$ \\
\hline
\end{tabular}

${ }^{1}$ World Geodetic System 1984 (WGS84)

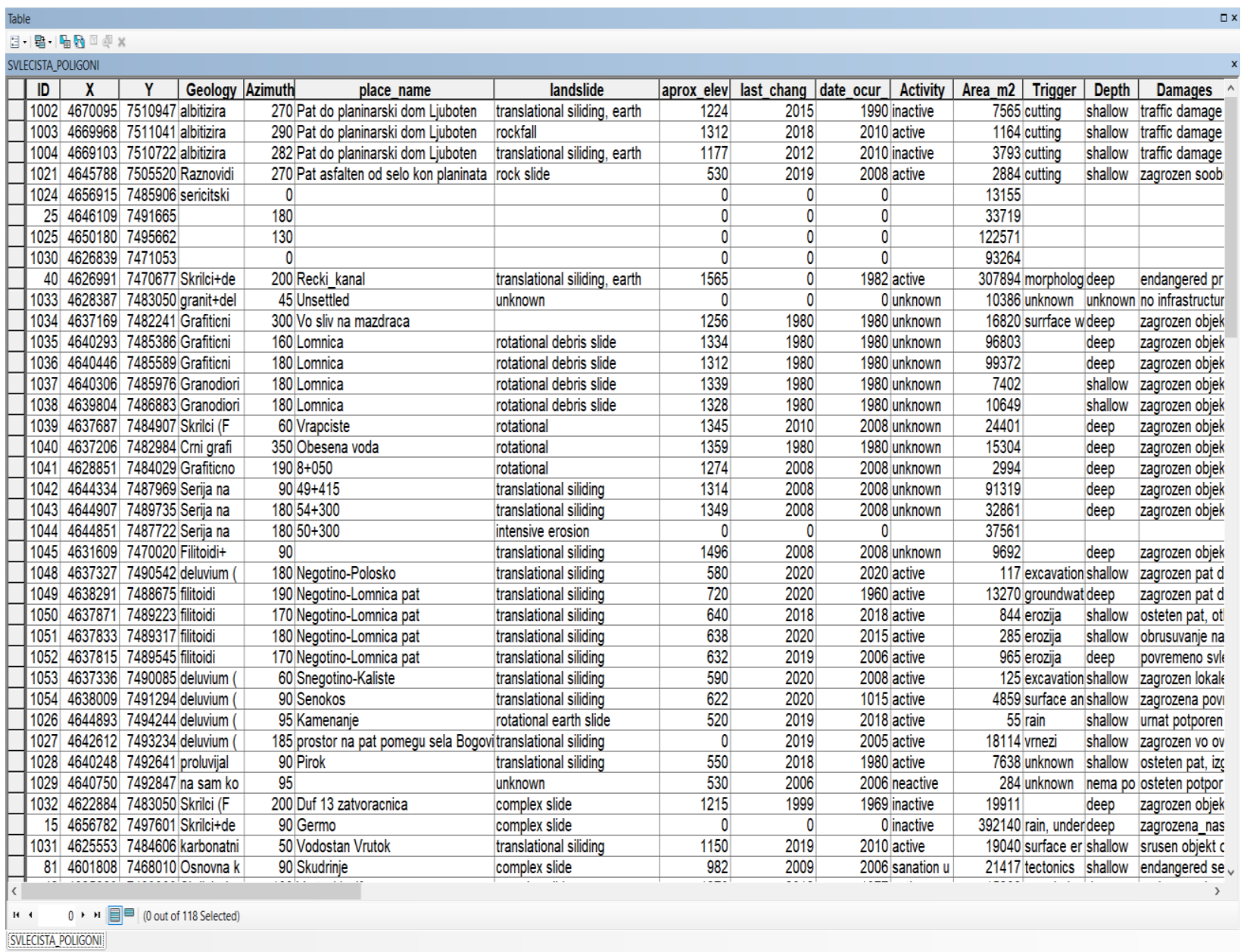

Fig. 2. Attribute table from the GIS regional database 


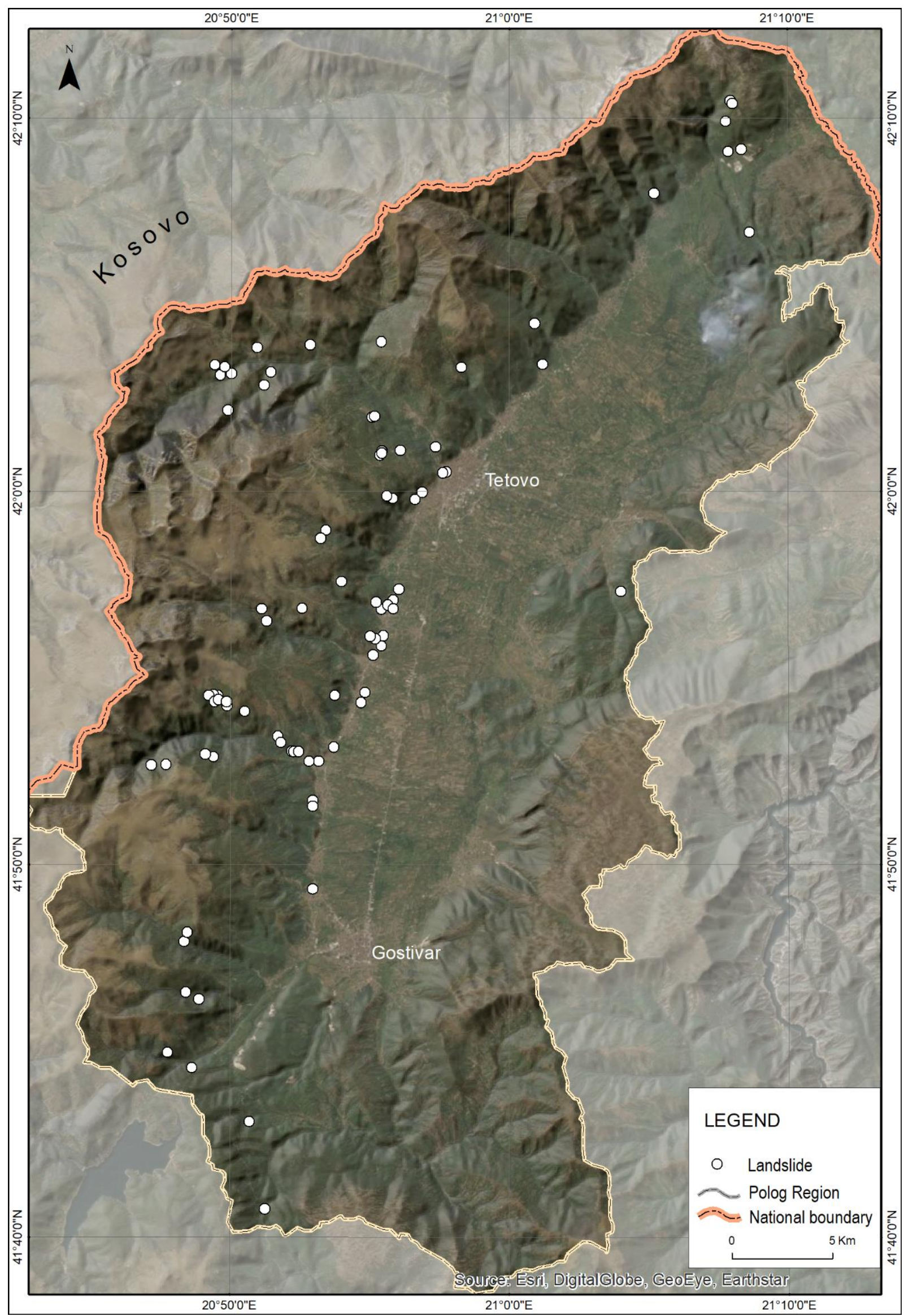

Fig. 3. Landslide inventory presented on a satellite imagery of the Polog region 


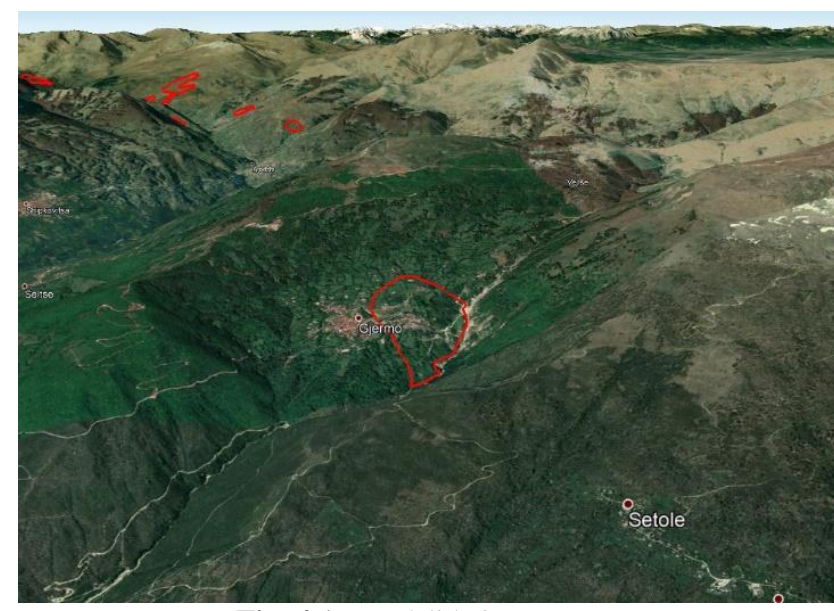

Fig. 4.1. Landslide in Đermo

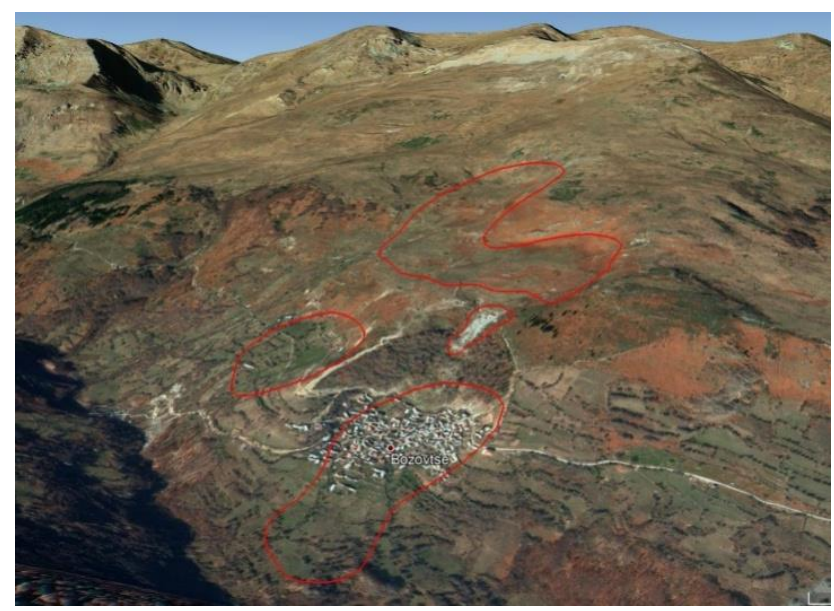

Fig.4.3. Landslides in Božovce

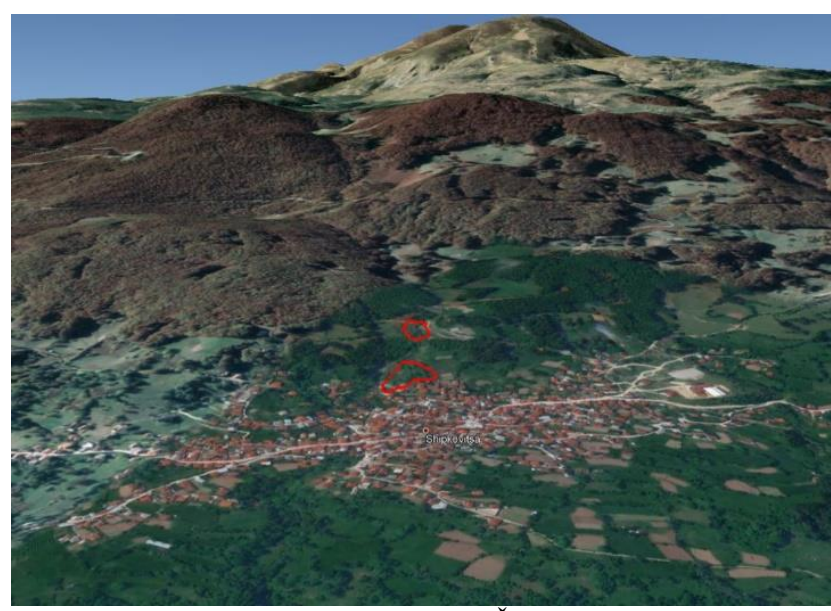

Fig. 4.2. Landslides in Šipkovica

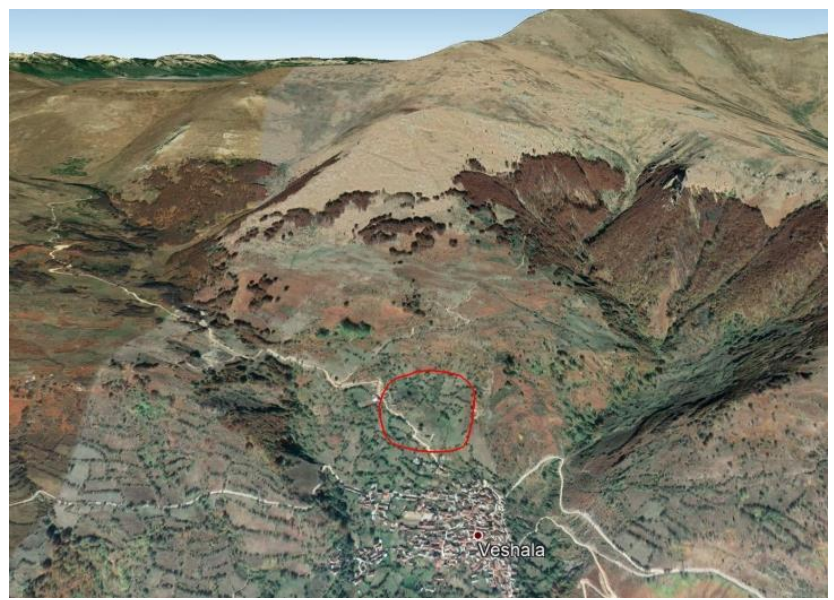

Fig. 4.4. Landslide in Vešala



Fig.4.5. Landslides around Bogovinje, Kamenjane etc. 


\section{LANDSLIDE DATA ANALYSIS}

In order to discover some patterns of landslide occurrences from different perspectives, the entire pool of data was analyzed. The following graphs (Figures 4-11) and tables were prepared.

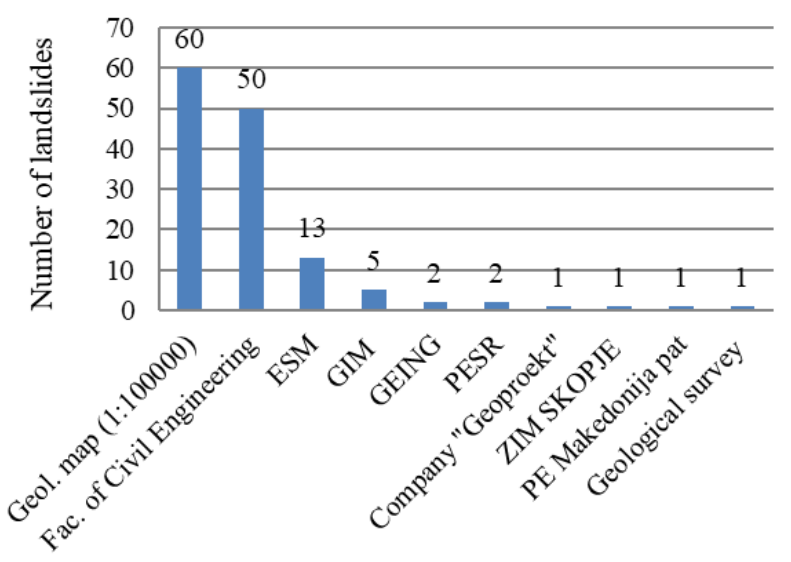

ESM - Power plants of North Macedonia

GIM - Civil Engineering Institute "Macedonia\#

GEING - GEING Krebs und Kiefer International et al. DOO

PESR - Public Enterprise for State Roads

ZIM Skopje - Institute for Testing of Materials and Development of New Technologies "SKOPJE" AD, Skopje

PE Makedonija pat - Public Enterprise "Makedonija pat"

Fig. 5. Sources of landslide data

Most landslide data originate from the Basic Geological Map in scale 1:100000 and appropriate working versions in scale 1:25000. Only the geological settings, the area and the direction of movement are known for these landslides. All other parameters cannot be found, except for landslides which are still active or partially reactivated slides. Namely, we have found that some of the landslides that were considered to be "younger" are actually part of older larger slides (e.g. cases in Bogovinje). Significant amount of data originates also from the reports archived at the Faculty of Civil Engineering in Skopje: 50 occurrences.

Almost half of the landslides affected directly the population and infrastructure in the Polog region, including disruption of the traffic flow and damages to the water channels of the "Mavrovo" hydrosystem. For 24 occurrences there have been registered damages, however the information is not available in the reports. Individual houses and settlements have been the subject of hazard in 16 events. For 33 landslides there is information for undertaking of certain sanation measures, although the smaller interventions are probably not registered in any documentation. The applied measures are usually presented with construction of retaining walls, surface and ground water drainage, and partial removal of sliding masses. In the case of Jelovjane landslide, an entire part of the settlement had to be replaced in another part of the village (13 houses).



Fig. 6. Landslide damage

Landslides were classified according to the depth of the sliding surface (Figure 7). The value of $2.0 \mathrm{~m}$ was considered as a separation criterion between shallow and deep landslides. It was found out that for half of the occurrences the depth of the sliding surface is unknown. It is worth mentioning that for some of the deep landslides, the sliding surface extended to depths of $20 \mathrm{~m}$ and even $\sim 40 \mathrm{~m}$.

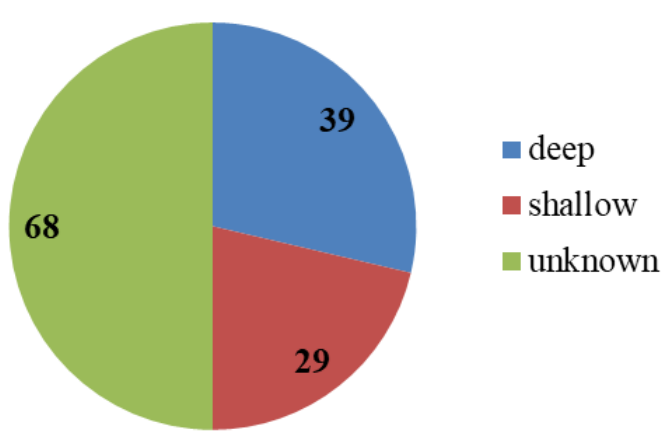

Fig. 7. Landslide classification according to depth of sliding surface

In relation to the trigger of landslide events, it was found that for most of the occurrences the factor is unknown (almost two thirds). This is a limiting factor and can lead to wrong conclusions considering the process of preparation of landslide hazard 
maps. From the occurrences with known triggers, it was found that most of the landslides are rainfall induced: some as a result of surface and ground water in the rock masses and debris, and relatively small number due to excavation. There is no information of some landslide being earthquake induced.

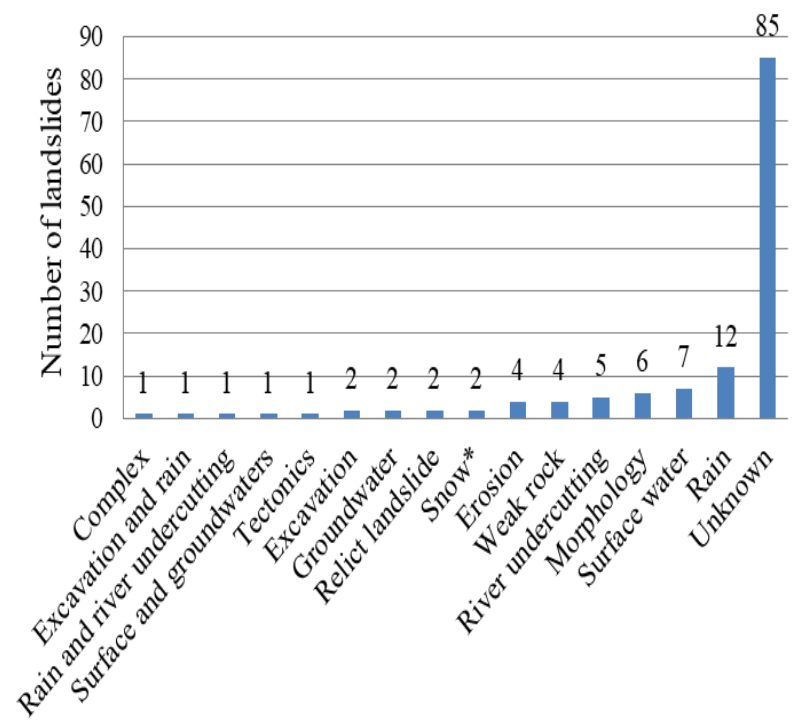

Fig. 8. Landslide triggers (*snow avalanche)

Table 2 presents landslide classification according to size of landslide area. Most of the landslides (55) belong to the category of large, 30 slides are classified as very large and 27 of medium size. Only 4 slides belong to the category of less than $100 \mathrm{~m}^{2}$ and 7 slides are $100-1000 \mathrm{~m}^{2}$. It is considered, how ever, that the number of these landslides is far greater, but they were not registered properly in the past. For thirteen occurrences the data on the area size is unknown.

T a b le 2

Landslide classification according to area size

\begin{tabular}{lcc}
\hline \hline Landslide size & Area in $\mathrm{m}^{2}$ & No. of landslides \\
\hline Very small & $<100$ & 4 \\
Small & $100-1000$ & 7 \\
Medium & $1000-10000$ & 27 \\
Large & $10000-100000$ & 55 \\
Very large & $>100000$ & 30 \\
Unknown size & & 13 \\
\hline \hline
\end{tabular}

Currently, a total of 37 landslides are considered to be active (Figure 9). These range from the type of shallow almost superficial slides to old deep slides. Some active occurrences are related to rock fall source areas. The upcoming LIDAR (LIght Detection and Ranging) and InSAR (Interferometric Synthetic Aperture Radar) analyses should help discover more active occurrences, thus this statistic category will be refreshed once these results for the entire region are available. Date of the first activation of sliding and current state of activity is available for certain number of landslides, although some dates are only indicative, i.e. from verbal communication with municipality representatives. Older data about landslide activity is very hard to obtain, since municipality representatives were not able to find documents older than 5 to a maximum of 10 years.

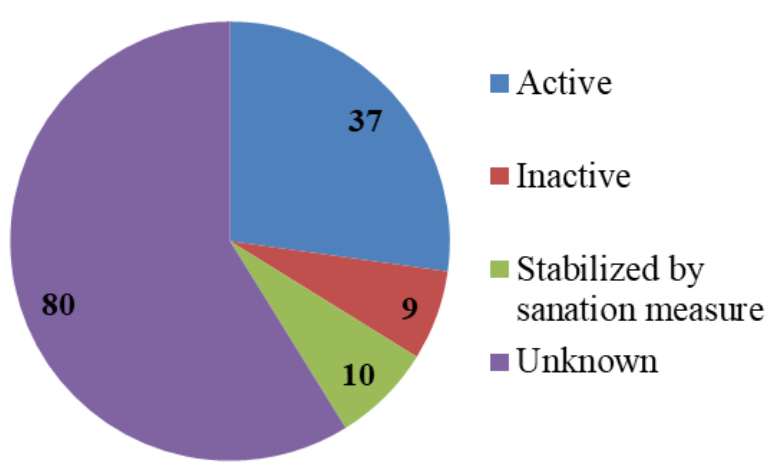

Fig. 9. State of landslide activity

Officially, the number of artificially stabilized landslides is ten, however it is considered that this number is much larger (having in mind that smaller slides in residential areas in many instances had not been registered in the first place).

The type of sliding mechanism according to Varnes and Cruden (1996) is unknown almost for half of the landslides (Figure 10). For known cases, 40 occurrences are classified as translational slides, 8 complex slides, 13 rotational slides, 5 rock falls, 3 rock avalanches, and one snow-rock-three avalanche and rock slide. One flow type of landslide is registered in historical archives, or may be treated as floods events rather than flow-like slides. The only registered events of this type are those from the 2015 mass sliding events. However, this finding should be considered as a limiting factor from several aspects, especially in regards to the selection of appropriate susceptibility (or hazard) method and calibration of such models. 


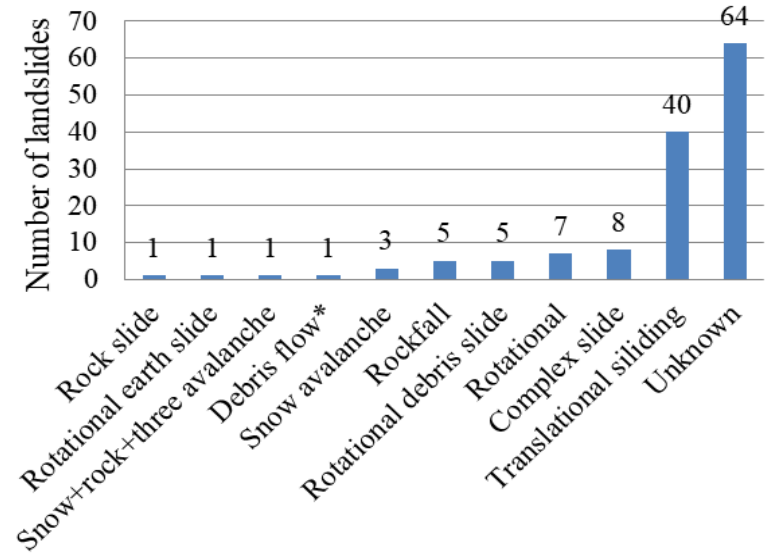

Fig. 10. Landslide mechanism classification

Considering the parameter of landslide movement direction, it is found that most landslides move in east-north-east to south-south-west direction. The polar plot is prepared to better present the distribution of landslide movement direction (Figure 11). Since many landslides move towards east or southeast, it should be expected that results of the InSAR analysis will give more insight into the landslides in the region (due to the satellite orbits used by ESA, the InSAR analysis is most reliable for landslides moving eastward).

Table 3

Classification of landslides according to lithological composition

\begin{tabular}{lc}
\hline \hline Lithological composition & No. of cases \\
\hline Schists overlain by debris, proluvial or artificial deposits & 51 \\
Varieties of schists & 10 \\
Limestone and limestone overlain by debris & 14 \\
Phylitoides & 13 \\
Debris & 9 \\
Granite overlain by debris & 8 \\
Cretaceous flysch & 5 \\
Proluvial material & 4 \\
Fluvioglacial deposits & 4 \\
Claystones, sandstones and alevrites & 3 \\
Granodiorites overlain by debris/proluvial deposits & 3 \\
Artificial fill & 3 \\
Marble and marble overlain by debris & 2 \\
Snow-tree-rock avalanche (mixed materials) & 2 \\
Avalanche & 136 \\
Diabase overlain by debris & 2 \\
Rhyolites overlain by debris & 1 \\
Pliocene deposits & 1 \\
\hline Total & 2 \\
\hline \hline
\end{tabular}


The upper table depicts that most landslides develop along the contact of debris and schist bedrock. The region is largely characterized by the presence of old Precambrian metamorphic complex, thus the terrain has a natural precondition for development of sliding processes. Some landslides are characterized by the presence of several different lithological units. In future hazard models, this parameter should be taken with great care.

\section{CONCLUSIONS}

During the preparation of the landslide inventory for the Polog region it was noted that the municipalities record limited amount of landslide data, even though based on verbal communication, events have been (and still are) very frequent. The total area of the currently mapped landslides is around $9.6 \mathrm{~km}^{2}$, which is less than $1 \%$ of the size of the mountainous part of the Polog region. So, these facts make the calibration of susceptibility and hazard models a very difficult exercise. Therefore, it should be continued to collect more data from all available sources in future and repeat (and improve) the hazard modeling process. Therefore, the landslide inventory should be uploaded in appropriate online GIS platform. In the first instance, basic data for landslides can be entered in the database by municipalities, and then checked by landslide experts.
In the following period it is planned to analyze the LIDAR survey that will be available for the region and introduce even more landslides in the inventory. However, since the region of interest is vast, this can be done only in an automated way and more detailed insight will be possible in more advanced stage of the study for particular catchments and sub-catchments.

Findings of the InSAR analysis will be combined with the landslide inventory, which will enable finding conclusions on the movement rates of detected sites. The information presented above leads to the conclusion that in the future studies for the region, appropriate attention should be given to development of susceptibility/hazard models for deep and shallow landslides as well as for flow-like event, although there is no historical information for the latter.

\section{REFERENCES}

Blahut J., Van Westen C. J., Sterlacchini S. (2010): Analysis of landslide inventories for accurate prediction of debris-flow source areas, Geomorphology, 119 (1-2), 36-51.

Calvello M., Pecoraro G. (2018): FraneItalia: a catalog of recent Italian landslides. Geoenvironmental Disasters, 5, 13.

Cruden D. M., Varnes D. (1996): Landslide types and processes. In: Turner A. K. \& Shuster R. L. (eds): Landslides: Investigation and mitigation. Transp. Res. Board, Spec. Rep., 247, 36-75.

Damm B., Klose M. (2015): The landslide database for Germany: Closing the gap at national level. Geomorphology, 249, 82-93.

ISPRA (2018): IFFI database.

http://www.isprambiente.gov.it/it/progetti/suolo-e-territori o-1/iffi- inventario-dei-fenomeni-franosi-in-italia. Accessed 28 September 2020

Hervás J., Bobrowsky P. (2009): Mapping: inventories, susceptibility, hazard and risk. In: Sassa K. \& Canuti P. (eds): Landslides - Disaster Risk Reduction. Springer, Berlin, pp. 321-349.

Hervás J. (2013): Landslide inventory. In: Encyclopedia of Natural Hazards; P. T. Bobrowsky (eds.): Springer,: Dordrecht, The Netherlands, pp. 610-611.

Jaupaj O., Lamaj M., Kulici H., Jusufati M., Plaku E., Gjeta I. (2017): Landslide Inventory Map of Albania, (C) Springer International Publishing AG. M. Mikoš et al. (eds.), Advancing Culture of Living with Landslides, 39-44.
Kirschbaum D.B., Adler R., Hong Y., Hill S., Lerner-Lam, A. (2010): A global landslide catalog for hazard applications: Method, results and limitations. Natural Hazards, 52, 561575.

Komac M. and Hribernik K. (2015): Slovenian national landslide database as a basis for statistical assessment of landslide phenomena in Slovenia. Geomorphology, 249, 94-102.

Li W., Liu C, Hong Y. et al. (2016): A public Cloud-based China's Landslide Inventory Database (CsLID): development, zone, and spatiotemporal analysis for significant historical events, 1949-2011. Journal of Mountain Science, 13 (7), 1275-1285

Mirus B. B., Jones E. S., Baum R. L. et al. (2020): Landslides across the USA: occurrence, susceptibility, and data limitations. Landslides.

Mrozek T., Kułak M., Grabowski D., Wojcik A. (2014): Landslide counteracting system (SOPO) - inventory database of landslides in Poland. In: Sassa K. et al. (eds): Landslide Science for a Safer Geoenvironment, Vol. 2. Springer, Heidelberg.

Pennington C., Freeborough K., Dashwood C., Dijkstra T., Lawrie K. (2015):: The National Landslide Database of Great Britain: Acquisition, communication and the role of social media. Geomorphology, 249, 44-51.

Peshevski I. and Jovanovski M. (2014): Recommendations for reduction of negative effects of landslides as important geohazard in R. Macedonia. Fourth Symposium for 
Geotechnics of Macedonian Association for Geotechnics. Vol. I.

Peševski I., Jovanovski M., Papić Br. J., Abolmasov B. (2015): Model for GIS landslide database establishment and operation in Republic of Macedonia. Geologica Macedonica, Vol. 29, No. 1, pp. 75-86.

Peshevski I., Peternel T., Jovanovski M. (2017):. Urgent need for application of integrated landslide risk management stretegies for the Polog region in R. of Macedonia. In: Advancing Culture of Living with Landslides. Vol. 5 Landslides in Different Environments. Eds. M Mikos et al. Springer International Publishing, pp. 135-145. DOI 10.1007/978-3-319-53483-1_43.

Peshevski I., Jovanovski M., Abolmasov B., Papić J., Marjanović M., Haque U., Nedelkovska N. (2019): Preliminary regional landslide susceptibility assessment using limited data. Geologica Croatica, 72, 1, pp. 81-92.
Petley D. (2012): Global patterns of loss of life from landslides. Geology, 40 (10), 927-930.

Sepulveda S., Petley D. (2015): Regional trends and controlling factors of fatal landslides in Latin America and the Caribbean. Natural Hazards and Earth System Sciences, 15, $1821-1833$.

Van den Eeckhaut M. and Hervás J. (2012): Landslide inventories in Europe and policy recommendations for their interoperability and harmonization. A JRC contribution to the EU-FP7 SafeLand project.

Van den Eeckhaut M., Hervás J. (2012): State of the art of national landslide databases in Europe and their potential for assessing landslide susceptibility, hazard and risk. Geomorphology, 139-140, 545-558.

Van Westen C.J., Castellanos E., Kuriakose S.L. (2008): Spatial data for landslide susceptibility, hazard, and vulnerability assessment: An overview. Engineering Geology,102 (3-4), $112-131$.

\title{
$\mathrm{P}$ е 3 и м е
}

\section{ПОДГОТОВКА НА КАТАСТАР НА ГИС ЗА СВЛЕЧИШТА ВО ПОЛОШКИОТ РЕГИОН}

\author{
Наташа Неделковска ${ }^{1}$, Игор Пешевски ${ }^{2}$, Милорад Јовановски ${ }^{2}$, Јован Папиќ $^{2}$, \\ Свемир Горин ${ }^{3}$, Иван Радевски ${ }^{3}$ \\ ${ }^{1}$ Геохиороконсалишин дОО, Скойје, \\ Ул. Манайо бр.7-2/5, МК-1000, Скойје, Рейублика Северна Макеgонија

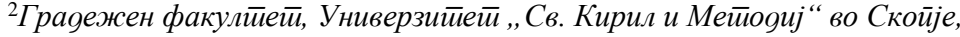 \\ Бул.Парииизански оореои бр.24, МК-1000, Скойје, Реиуублика Северна Макеgонија

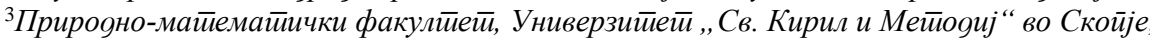 \\ ул. Архимеgова 3, МК-1000, Скойје, Рейублика Северна Макеgонија \\ n_nedelkovska@hotmail.com
}

Клучни зборови: свлечиште; катастар; Полошки Регион

Во овој труд е прикажана подготовка во рамките на ГИС (географски информациски систем) на катастар на свлечишта во Полошкиот Регион. За оваа цел: беа преземни бројни активности: анализа на сопствени податоци за свлечиштата, посети на локации забележани во анкетите што ги пополнија општините, дигитализација на свлечишта од стари геолошки карти во размер 1: 25000, анализа и дигитализација на свлечишта од архивата на Геолошкиот завод на Македонија, интервјуа со вработени и колеги во пензија од геотехнички компании, анализа на свлечишта по каналите на системот „Маврово“, посета на Државниот универзитет во Тетово и заедничка посета на терен, и посети на повеќе геотехнички компании во С. Македонија. Бидејќи ова е прв обид да се формира регионален катастар на свлечишта во С. Македонија, во овој труд се презентира усвоената структура на катастарот. За да се види какви придобивки можат да се добијат од постоењето на ваков катастар, во трудот се презентирани некои од најважните заклучоци за свлечиштата. Моментално катастарот на свлечишта се состои од 136 појави и треба навреме и соодветно да се ажурира. Главните заклучоци поврзани со распределбата и карактеристиките на свлечиштата покажуваат дека идните анализи треба да вклучат подготовка на модели за подложност/ризик од плитки и од длабоки свлечишта, како и течишта. Планирано е во следните фази на истражување да се анализира снимањето LIDAR кое се подготвува за регионот и да се вклучат повеќе свлечишта во катастарот на свлечишта. Исто така, заклучоците од анализите InSAR ќе се комбинираат со катастарот на свлечишта, што во иднина ќе овозможи да ги коментираме стапките на поместување на детектираните локации. Последните два пристапа ќе бидат предмет на идни трудови. 